\title{
"Invented tradition": Restoration and Reconstruction Process of Rural Institutions on Lý Sơn Island, Quảng Ngãi Province, Vietnam
}

\author{
Cao Nguyen Ngoc Anh \\ Ho Chi Minh City University of Culture, 51 Quoc Huong Street, Thao Dien Ward, District 2, Thu \\ Duc City, Ho Chi Minh, Vietnam.
}

\begin{abstract}
This article discusses and analyses the restoration and reorganization of traditional Vietnamese village institutions in Lý Sơn Island, Quảng Ngãi Province since Đổi mới (Reform, 1986).After understanding this topic, we conducted qualitative research on ethnographic field surveys during the intermittent period from March 2008 to August 2019.Our survey results show that the villagers' self-government organization in Lý Sơn has been cultivated from the beginning of the establishment of the Vietnamese to today, forming a "village - hamlet neighborhood (sub-hamlet)" hierarchy (làng - thôn - lân). Despite the severe effects of destruction and war, the system is stable and is playing an increasingly important role in maintaining the religious practices of the community. We use Eric Hosbawm's concept of "invented tradition" to explain the changes in rural systems, especially the interaction and mediation between tradition preservation and reconstruction to meet the needs of the community and adapt to the specific social environment of each period.
\end{abstract}

Key words: Lý Son, Vietnamese, village institution, inventing tradition, reconstruction of culture

\section{Introduction}

"Invented tradition"is a term proposed by the British historian Eric Hobsbawn in his well-known work The Invention of Tradition. He said:"invented tradition" is taken to mean a set of practices, normally governed by overtly or tacitly accepted rules and of a ritual or symbolic nature, which seek to inculcate certain values and norms of behaviour by repetition, which automatically implies continuity with the past."1

According to Hobsbawn, the past traditions are not static or framed, but is constantly changing and being invented. This process takes many years, combining the old and new elements, the "tradition" and "modernity", showing the trend of adjusting traditional culture in various periods to meet the needs of the community and social environment. Many researchers at home and abroad are using the concepts of "inventing tradition" and "reconstructiing tradition" to analyze cultural dynamics in the ever-changing social environment, such as Yang Minchuan (1994), Klein John (1999), Lương Hồng Quang (2011), Lương Văn Hy \& Trương Huyền Chi (2012), Nguyễn Thị Phương Châm (2016), etc.

When discussing Hosbawn's views, the authors Lương Văn Hy and Trương Huyền Chi (2012) put forward the following views on the process of inventing tradition when they were studying the annual public rituals of Hoài Thị Village in Northern Vietnam:"The process of inventing tradition is a continuous process. It involves the negotiation of multiple actors with diverse voices, who have different voices, various local and cross-local ideologies, and have complex dynamics in complex multi-dimensional relations between local communities as well as between

\footnotetext{
${ }^{1}$ Eric Hobsbawn \& Terence Ranger: The Invention of Tradition (Sáng tạo truyền thống), Cambridge University Press, 2000, p.1.
} 
the local communities and the state. The outcome of the negotiation process at the community level is largely unpredictable" ${ }^{2}$.

Therefore, the process of "inventing tradition" is the process of restoring and reconstructing a traditional culture with the adoption, formation, and development of new cultural elements. Using the above-mentioned "inventing tradition" view, we believe that the Lý Son islanders tend to reconstruct and invent traditional culture by restoring and rearranging their traditional elements to meet the actual needs of the local community. According to the social background of each specific period, the traditional rural system is converted between the traditional and the modern, so that the old and the new elements merge together to meet the needs of the community.

In this article, we use ethnographic research methods and biblical methods for analysis.The author of this paper conducted field surveys during the intermittent field survey from 2008 to August 2019 and collected from Lý Sơn residential communities through in-depth interviews and participatory observation methods. In specific, the author participated in a meeting to propose the restoration plan of An Vĩnh Village in November 2009 and participated in public temple ceremonies in 2011, 2016, 2017, 2018, and 2019. In addition, the bibliographic files include documents and annual reports stored by the Lý Son Island District People's Committee as well as published studies related to the research topic in the library system are properly used in this research.

\section{The Vietnamese community in Lý Sơn Island}

Lý Sơn is an island area in Quảng Ngãi Province, with an area of 9,965 square kilometers and a population of 20,195 people. It is located about 25 nautical miles from the mainland to the northeast, including a large island (Cù Lao Ré) and a small island (Cù Lao Bờ Bãi) ${ }^{3}$. According toĐịa chí Quảng Ngãi (Geographical Records of Quảng Ngãi), The Vietnamese people of northern Vietnam immigrated to Quảng Ngãi in three waves. In 1402, during the Hồ Dynasty (1400-1407), they first moved to the Thăng Hoa and Tư Nghĩa areas. The second wave was during the reign of King Lê Thánh Tông in 1471. The third wave was in 1558 when Lord Nguyễn Hoàng ${ }^{4}$ moved and expanded his territory south.These are the three main immigration waves organized by the state, except for the free immigration of farmers from the north during the Trần Dynasty (1225-1400) and the Lê trung hưng periods (1533-1789) ${ }^{5}$.Vietnamese residents began to open villages on Lý Son Island from the end of the 16th century to the beginning of the 17th century. InNon nước xú Quảng(The Quảng Region), Phạm Trung Việt believes that 1604 was when the first Vietnamese migrated to Lý Sơn Island ${ }^{6}$. They were from An Hải, Sa Kỳ areas of Bình Sơn and Sơn Tịnh Districts. In the fieldwork, someone told me story about the ancient people reclaiming this land: "In Lý Sơn, there is a temple dedicated to 15

\footnotetext{
${ }^{2}$ Lương Văn Hy \& Trương Huyền Chi:“Thương thảo để tái lập và sáng tạo "truyền thống”: Tiến trình tái cấu trúc lễ hội cộng đồng tại một làng Bắc bộ (Negotiation to Re-establish and to Invent "Tradition": The Re-structuring of Community Festival in a North Vietnamese Village), in Nhũng thành tưu nghiên cứu bước đầu của Khoa Nhân học (Primary research achievements of the Department of Anthropology), ed. the Department of Anthropology, VNUHCM, pp. 235-279, Vietnam National University - Ho Chi Minh City Press, 2012,p. 235.

${ }^{3}$ Chi cục Thống kêHuyện Lý Sơn tỉnh Quảng Ngãi(Bureau of Statistics of Lý Sơn District, Quảng Ngãi Province), Niêm giám thống kê huyện Lý Sơn (Lý Sơn District Statistical Yearbook), 2017, p.1.

${ }^{4}$ Nguyễn Hoàng (1525-1613), an official of the Lê Dynasty, escaped to the region where it is now the Central of Vietnam to establish the Kingdom of Đàng Trong (Cochinchine, 1600-1789). King Nguyễn Huệ unified both parts of the country in 1789.

${ }^{5}$ Ủy ban nhân dân tỉnh Quảng Ngãi (People's Committee of Quảng Ngãi Province): Địa chi Quảng Ngãi (Geographical Notes of Quảng Ngãi), Encyclopedia Press, Hanoi, 2008.

${ }^{6}$ Phạm Trung Việt: Non nuớc xú Quảng (The Quảng Region), Youth Press, Ho Chi Minh City, 2005, p.32.
} 
pioneers (reclaimation precedors) from 15 different families, who are believed to be the first to explore this island. Among them, pioneers of 7 families including Phạm Khắc, Phạm Văn, Võ Xuân, Võ Văn, Lê, Nguyễn, and Đặng reclaimed, cultivated and from An Vĩnh Village on the West of Lý Sơn Islan, while pioneers of the other 8 families including Nguyễn, Dương, Trương, Trần, Võ, Nguyễn Đình, Nguyễn Văn, and Lê formed An Hải Village on the vast eastern side of the island" 7 .

The documents and stories above show that the Vietnamese people have come to Lý Sơn Island quite early, in the 16th century. The livelihoods of generations of residents are very diverse, such as agriculture (growing onions, garlic), fishing, etc.During the early reclamation of the island, residents faced many difficulties, so they established religious institutions as important spiritual support.Therefore, the current religious institutions and the deity pantheon system in Lý Sơn Island are very rich. Each religious site worships different gods and is divided according to the hierarchical system of villages, hamlets, and neighborhoods(sub-hamlets).

The organizational structure of villages in Lý Sơn Island before 1945

Địa chí Quảng Ngãi (2008) I noted that the villages of the Quảng Ngãi region have first established during the Lê Dynasty (1428-1533), but mainly during the Nguyễn Lords period (Đàng Trong, 1600-1789). The Nguyễn lords established administrative institutions based on the three levels, namely, đạo (province), tổng (county), and làng (village) ${ }^{8}$. Similar to Vietnamese villages in many other regions, generally in the Quảng Ngãi area, especially on Lý Sơn Island, the formation of Vietnamese villages is related to the migration and land reclamation process since the 16th century. As mentioned above, the people of An Hải and Sa Kỳ Villages in Bình Sơn and Sơn Tịnh Districts (Quảng Ngãi Province) moved to Lý Sơn Island during many periods; Therefore, they named the villages of Lý Sơn Island with the village names on the mainland (An Hải and An Vĩnh) to commemorate the ancient motherland.

After reclaiming land to establish villages, An Hải and An Vĩnh pioneers established an autonomous organization to communicate, maintain stable order and perform common village tasks.Lý Sơn's village management agency was organized through the hierarchical system from "village" to "hamlet" then to "sub-hamlet/neighborhood" and each management level had its own agency to handle community work. The village organization of Lý Sơn Island before 1945 is as follows:

Table 1: The organizational structure of villages in Lý Son Island (The period from the early Nguyễn Dynasty (1802) to 1945)

\footnotetext{
${ }^{7}$ Author's fieldwork notes, April, 2009.

${ }^{8}$ Ủy ban nhân dân tỉnh Quảng Ngãi (People's Committee of Quảng Ngãi Province):Địa chí..., p.324.
} 


\section{VILLAGE (LÀNG)}

(Head of Village Notables Committee/Village Chief, Village Chief Administrator, Village's Bureaucratic Committee including members incharge of Village's Five Civil Affairs Committee: Hương Bộ (Village Household Affairs), Hương Bổn (Village Financial Affairs), Hương Dịch (Village Service), Hương Kiểm (Village Inspection), Hương Mục (Village Public Work)

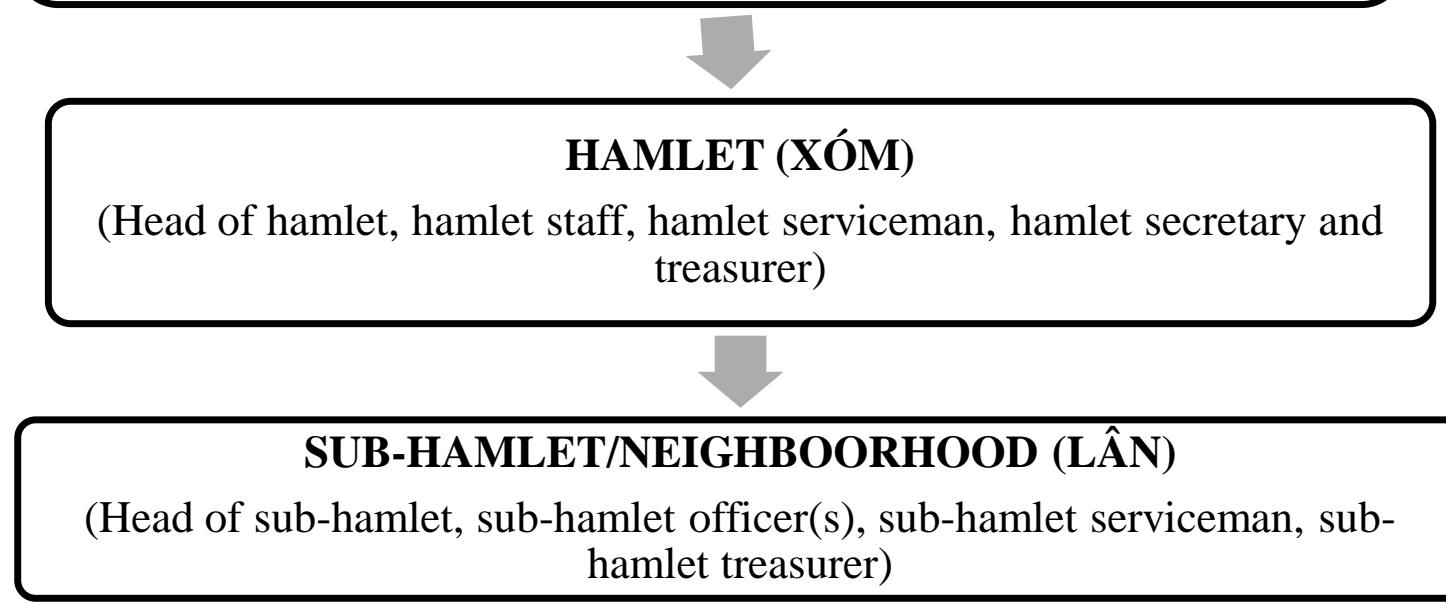

(Source: Author's fieldwork notes, 2019)

The village organization of Lý Sơn Island before 1945 was organized strictly from village level down to hamlet and then neighborhood level.

\section{Village}

By studying the work Văn hóa truyền thống của cu dân đảo Lý Sonn (The traditional culture of Lý Sơn Islanders, 2002) and based on in-depth interviews with the elderly in Lý Sơn, we confirm that the village is headed by Cả làng (Head of the Village Notables Committee/ "Village chief"), who was assisted by Lý truoong(Village chief administrator) and the "Ngũ hương bộ (Five Civil Affairs Committee)", includingHousehold Affairs, Financial Affairs, Village Service, Inspection, and Public Work ${ }^{9}$.

Cả làng (or ông Cả,Head of Village Notables Committee)is the head of the village, responsible for the main sacrifices to the public temples and religious facilities managed by the village. Mr. V.H.Đ said: "My grandparents told me that in the past, Cả làng is the highest leader of the entire village. Everyone must obey him. In the past, Cả làng was a person with an outstanding reputation, fluent in Chinese characters, and knowledgeable about the village, so he was nominated for this position.People in the village, if they had something to report to Cả làng, they must say "Dear Sir (Dạ, thưa)" at the beginning to show respect"10.

According to the elderly, Cả làngin the old time must be the person who "had a prosperous and happy family and was good at both literature and mathematics”. In addition, the person selected as Cả làng must be "a wealthy man" because:

In the past, the royal seals of the village were kept in Cả làng's home. At the end of this year, the villagers must organize a parade to bring the seals from $C a$ làng's house to the public temple. On the third day of the Lunar New Year, villagers held another ceremony to

${ }^{9}$ Ủy ban nhân dân tỉnh Quảng Ngãi \& Sở Khoa học công nghệ và Môi trường (People's Committee of Quảng Ngãi Province \& Department of Science, Technology and Environment): Văn hóa truyền thống đảo Lý Sonn (The traditional culture of Lý Sơn Island), Quảng Ngãi Printing Factory, Quảng Ngãi, 2002, p.56.

${ }^{10}$ Quoted from an in-depth interview with Mr. V.H.Đ, 84 years old, in Lý Sơn on July 2016. 
bring the seals from the public temple back to Cả làng's house. Then during the holiday, Lunar New Year, leaders of the village, hamlets, and neighborhood/sub-hamlets came to Cả làng's house to pay the courtesy for the royal seals, Cả làng had to prepare meals to entertain them. Therefore, $C a ̉$ làng in the village must have appropriate financial conditions so that he could preside over these rituals at home" ${ }^{11}$.

In addition to understanding customs, etiquette (rituals), and having proper financial conditions, Cá làng must also be a descendant of one of the 15 pioneers' families. Mr. V.M.T described: “If you one was not the descendant of one of 15 pioneers, he could not be elected to hold the position of Cả làng.Every time Cả làng was elected, representatives of 15 ancient pioneer families, the village chief administrator, the heads of each hamlet and neighborhood would vote. The old grandparents said that in the past, the descendants of other lineages (arrived in Lý Sơn later than the first waves) were not allowed to be candidates. This fact was clearly stipulated in the village convention” ${ }^{\prime 2}$.Therefore, $C a$ làng must fully meet the following basic conditions: age, understanding of village customs, better economic conditions, and descendants of Lý Sơn Island's pioneerfamilies. During his four-year term in the position, Cả làng was engaged in ritual work, served the role of liturgical master of all ceremonies in public temples, and resolved all disputes in the village (based on village convention). In addition to Cả làng, the village management apparatus also includes village chief administrator and five officials in charge of five public councils.

$L y$ truóng(village chief administrator) is the "administrative village head, similar to Xã quan(commune's head official)or Xã truoỏng (commune chairman) in other historical periods. Since the reign of Minh Mạng (1820-1840), the title Lý truoóng has been proposed and applied. Lý truơng was the grassroots leader of the feudal government and then the colonial government"13. King Minh Mạng specified that Lý truoơng must be elected by the people. "Lý trưởng and Lý phó (deputy chief administrator) must be hard-working and diligent people, and must be voted unanimously by the villagers. After that, the county governor carefully reviewed it and then reported it up to issue diplomas and carpentry. After working for three years, they would be evaluated by their superiors. If they were rated well, they would be rewarded;if they were rated poorly or embezzled, they would be fired and fined” ${ }^{14}$. In Lý Sơn Island, Lý truơngmainly mainly handled the administrative affairs of the village, urging people to perform certain duties to the state, such as taxation, military service, farming, and land management ${ }^{15}$. In addition to Lý truởng, there are Five Civil Affairs Committee members. Among them, Hương bổn (member in charge of of the finances of the village), served as Lý phó (deputy chief administrator), who also served as the secretary to record all expenditures of the village. Huong kiểm(Village Inspector) is responsible for ensuring the safety of the village.Huong dịch (Village serviceman) was responsible for preparing sacrificial objects and other civil works. Huong muc (member in charge of the public work of the village) was responsible for supervising and maintaining roads, public buildings, temples, pagodas and temples, and other public works. The

\footnotetext{
${ }^{11}$ Quoted from an in-depth interview with Mr. V.M.T, 38 years old, in Lý Sơn on August 2, 2019.

${ }^{12}$ Quoted from an in-depth interview with Mr. V.M.T, 38 years old, in Lý Sơn on August 16, 2019.

${ }^{13}$ Anonymous: "Bảng tra Các chức quan, phẩm tước, học vị thời phong kiến Việt Nam (Checklist of official titles and degrees in Vietnam's feudal system)”, http://hotovietnam.org/Tin-tuc-va-Su-kien/Khoa-hoc--Lich-su/175-Bangtra-Cac-chuc-quan-pham-tuoc-hoc-vi-thoi-phong-kien-Viet-Nam, Accessed on September 23, 2020.

${ }^{14}$ Bảy Tám (compiled): “'Luật làng' thời phong kiến Việt Nam (Bài 1): Đội ngũ 'dân quan' (The "Village Law" in the Feudal System of Vietnam (Part 1): The "civilian" team)”, https://baophapluat.vn/dan-sinh/luat-lang-thoi-phongkien-viet-nam-bai-1-doi-ngu-dan-quan-392784.html, Accessed on September 23, 2019.

${ }^{15}$ Ủy ban nhân dân tỉnh Quảng Ngãi (People's Committee of Quảng Ngãi Province):Địa chí..., p.63.
} 
Five Civil Affairs Committee assistedCả làng and $L \dot{y}$ trương to perform a series of duties to the state such as supervisingtax payment and managing the maintenance of security and ritual affairs of the village.

Therefore, Cả làng, Lý trương, and members of the Five Civil Affairs Committeejoint the role in resolving the internal affairs of the village, the conflicts between village members, and especially the management of village worship according to traditional custom.

\section{Hamlet (Xóm)}

In the Nguyễn Dynasty, the unit below the village level in Lý Sơn wasxóm (hamlet). Xómwas also a settlement for families in the same geographic area, but smaller than a village.Therefore, a village could have many hamlets. In the Central region in general and Lý Sơn Island in particular, the old xóm (hamlet) was the unit equivalent to the current thôn (administrative hamlet). In Lý Sơn, An Vĩnh village has 2 hamlets (East hamlet and West hamlet) and An Hải village has 4 hamlets (East hamlet, West hamlet, Trung Yên hamlet, and Trung Hòa hamlet). The head of the hamlet was Chủ xóm (Head), and his assistants included hamlet officer(s), serviceman, and hamlet treasurer

Chủ xóm(Head of hamlet) was the leader of each hamlet. According to the villagers' convention, Chủ xóm was selected by the hamlet residents according to his age (usually old-aged man), reputation, and expertise in hamlet communities' administrative, social and ritual activities (he was "the one who wrote the ritual oration documents of the hamlet" ${ }^{16}$. In a field survey conducted in Lý Sơn in February 2019, the author met and talked with Mr. N.C (former Chủ xóm of West hamlet, An Hải Village) when he was holding the year-end ritual for a neighbor at Tam Tòa Temple. He said: "On the first day and the end of the new year, I usually help hold "ceremonies" in temples and shrines because people pray to the gods to help them do good business at the beginning of the year. At the end of the year, they return to thank the gods. Ordinary people do not understand how to perform the worship ceremony; therefore, they must seek help fromChủ xóm. Chủ xómorganizes the ceremonies and help them "communicate" with the gods"17.

It can be said that Chủ xóm played a leading role by making sacrifices in religious institutions such as temples and shrines managed by hamlets, participating in the ceremonies of village public temples appointed by Cả làng, and participating in meetings to solve civilian problems of the village (if any). Chủ xóm was responsible for handling all hamlet issues before submitting them to Cá làng, Lý truoơng and members of the Five Civil Affairs Committee. In addition to Chủ xóm, the residents of the hamlet also elected other people as assistants of Chủ xóm to execute and handle the affairs of the hamlet: Tri ấp (hamlet staff), Chấp sụ (hamlet serviceman), and Thu bổn (hamlet secretary and treasurer).

Tri âp(hamlet staff) was Chủ xóm's assistant. He was trusted by local residents based on knowledge standards about sacrifice and community reputation. In the ceremony, Tri ấp was responsible for supervising the offering sacrifices to the gods and acting as the assistant of the ceremonial master. In addition to Tri áp andChấp sụ(hamlet serviceman) were the persons responsible for buying sacrifices in preparation for the ceremonies.Thu bổn(hamlet secretary and treasurer) was the secretary and treasurer of the hamlet.All contributions made by the people to

\footnotetext{
${ }^{16}$ Author's fieldwork notes, February, 2009.

${ }^{17}$ Quoted from an in-depth interview with Mr. N.C, 73 years old, in West Hamlet, Lý Sơn on February 26, 2019.
} 
the hamlet on the occasion of a public holiday or the reconstruction of public cultural relics were carefully recorded by Thu bổn.

As a matter of fact, similar to village-level management, the hamlet residents elect members to perform sacrificial activities and solve community problems on their behalf.

\section{Lân (Neighborhood/Sub-hamlet)}

"Lân”(Neighborhood/Sub-hamlet)is a term used by the people of Lý Sơn to refer to "a group of families of about 40 self-linked households" ${ }^{18}$. Lân is smaller than xóm, hence, two or more lân form one xóm. An Vĩnh Village has 7 lân ${ }^{19}$ (namely, Vĩnh Lộc, Vĩnh Xuân, Vĩnh Lợi, Vĩnh Thành, Tân Thành, etc.), and the same is true of An Hải Village (namely, Đông Thạnh, Đông Hải, Trung Chánh, Thuận An, Đồng Hộ, Lý Nhơn, and Thái Bình Ca). In order to manage the affairs of the neighborhood (lân), people also elect Chủ lân (the head of the neighborhood) and his assistants, including tri lân (lân officer), chấp sụ (serviceman) and thu bổn (secretary and treasurer), for a term of four years.

Chủ lân(the head of the neighborhood)must have a high reputation and are elected by 40 families every 4 years. On Lý Sơn Island, when lân was formed, people established religious institutions in their lân. Therefore, Chủ lân was also a celebrater of the neighborhood's ceremonies and participated in the ceremonies of the village public temple allocated by Cả làng. Chủ lân was supported by tri lân (neighborhood staff) and lân's cult committee.

Tri lân (neighborhoodstaff) was Chủ lân’s assistant, supervising the offering sacrifices and other liturgical affairs.Chấp sụ (serviceman) was the person in charge of preparing all ceremonial offerings for the ceremonies in the neighborhood.Thu bổn was lân's secretary and treasurer, who had to record all contributions made by the neighborhood residents at the annual ceremony and for public constructions.

It is clear that the self-governing apparatus on Lý Sơn Island from the early Nguyễn Dynasty to 1945 was organized in vertical order, from làng (village) down to xóm (hamlet) and lân (neighborhood). Correspondingly, residents at all levels will elect representatives to handle their internal affairs. It can be said that the main task of this self-governing apparatus was to take care of the sacrifices at the village's religious establishments every spring and autumn and on the days of worship corresponding to the gods being worshipped. Even if cả làng, chủ xóm, and chủ lân did not enjoy their economic benefits, they were respected by the villagers.

\section{Restoration and Reorganization of Rural Institutions: Lý Sơn Island residents' "Inventing Tradition" process since Đổi mới $i^{20} 1986$}

The restoration and reorganization process of the Lý Sơn rural organizations is a long process, in which people of different generations continue to invent their own traditions.Compared with the traditional rural organizational structure in Lý Sơn before 1945, the author learns that there are many similarities in the form and organizational structure of today. However, with the integration of old and new, traditional and modern in reality, internal details such as the management apparatus, voting standards, and ceremonies have all changed. The author claims that the integration of various modes in the current village organizational structure and activities in Lý Sơn is a restructuring of traditional culture.The concept"restructuring of traditional culture”has been mentioned in the village research of Minchuan Yang (1994), Kleinen John

\footnotetext{
${ }^{18}$ Ủy ban nhân dân tỉnh Quảng Ngãi \& Sở Khoa học công nghệ và Môi trường (People's Committee of Quảng Ngãi Province \& Department of Science, Technology and Environment): Văn hóa truyền thống...,p.65.

${ }^{19}$ In my understanding, "Lân”is equivalent to "ấp" in Southern Vietnam.

${ }^{20}$ Đổi mới: Reform Policy.
} 
(1999), Lương Hồng Quang (2011), Lương Văn Hy (2012), Nguyễn Thị Phương Châm (2016), which is understood as "complementary restoration, rearranging traditional cultural elements so that they can meet people's needs for cultural elements in a contemporary environment" ${ }^{21}$.

The post-Đối mói period marked the revival of cultural activities of the residential community on Lý Sơn Island.In 1945, the announcement of King Bảo Đại (1913-1997, r. 1926-1945)'s abdication marked the end of several thousand years of feudalism in Vietnam's history. The period of 1945-1975 was the period when the country entered the wars against the French and the American, many religious sites in Lý Sơn were destroyed and no community festivals were organized, so rural institutions were almost inactive.In 1986, the Đổi móri policy created a turning point for the country's development in all aspects, especially in the cultural field. Especially in 1998, the Central Committee of the Communist Party of Vietnam issued Article VIII of Resolution No. 5, that is, "Developing a progressive Vietnamese culture steeped in the "national essence""', which is of great significance for the restoration, preservation, and promotion of Vietnam's heritage value after implementing the Đổi mói policy for 13 years and preparing to enter a period of integration with the world. Article 8 of Resolution TW5 is considered to be a prerequisite for the "restoration" of cultural customs. In addition, the "Cultural Heritage Law" was promulgated in 2001, followed by the "Religion and Belief Law", which specifically changed the concept of folk beliefs and religion. Religion is no longer the "opium of the people" but "is the spiritual need of a part of the people" and "has cultural and ethical values consistent with the new regime" ${ }^{22}$.This is an important theoretical basis for changing beliefsreligion in terms of national cultural policy. When interviewing the village head on Lý Sơn Island about the process of village organization construction, the author learned that: "During the war, this institution hardly had any activity, because, after 1945, these villages established management committees mainly to perform ceremonial activities only.During the war, public temples and other temples in the village were destroyed or recruited as the headquarters of the resistance forces, and then abandoned, with almost no rituals. Until the 2000s, with the restoration of public temples and other religious sites, these institutions were vigorously restored ${ }^{23}$.

According to the Summary Report on the Implementation of Resolution No. 2006-NQ/TU of Quảng Ngãi Province Tourism Development Committee of the Provincial Party Committee during the period 2006-2010 and Orientation to 2015 (issued on October 31, 2006) and Conclusion 136 KL/TU of the 7th Provincial Party Committee Conference on Quảng Ngãi Tourism Development 2011 - 2015 and Orientation to 2020 (No. 42 BC-HU / 2020, issued on February 1, 2016), mentioned the investment in the construction and decoration of worship facilities in Lý Sơn as follows: Quảng Ngãi Province has invested totally 17.15 billion VND to build a dike against landslide in Chùa Hang Temple area (700 million VND), to restore and decorate the Hoàng Sa (Paracel) Fleet Gallery, An Vĩnh Village Public Temple (16 billion VND); Hải An Village Public Temple (150 million VND) and the Lý Sơn Ancient Pioneers Shrine (300 million

\footnotetext{
${ }^{21}$ Nguyễn Thị Phương Châm \& Đỗ Lan Phương: Làng ven đô và sụ biến đổi văn hóa - Truòng hơp làng Xuân Đỉnh, huyện Tù Liêm, TP. Hà Nội (Peri-urban village and cultural change - Case of Xuân Đỉnh village, Từ Liêm district, Hanoi),Social Sciences Press, 2016, p.260.

${ }^{22}$ Politburo Resolution No. 24 NQ-TW of October 16, 1990, term VI on "Strengthening religious work in a new situation,

http://btgcp.gov.vn/Plus.aspx/vi/News/38/0/240/0/1081/Tu_su_doi_moi_nhan_thuc_den_sudoi_moive_Chinh_sach _Ton_giao, Accessed on September 23, 2020.

${ }^{\overline{23}}$ Author's fieldwork notes, August, 2009.
} 
VND) ${ }^{24}$. With the changes in the policies of many monuments, the worship facilities in Lý Sơn were restored, re-decorated, and reconstructed. Since then, ceremonies and festivals have also been "restored".In parallel with the "restoration" process, Lý Sơn's rural institutions were restored to take over work related to sacrifices in religious institutions. The survey in Lý Sơn results shows that, in addition to the state management agency, local residents still use the "làng - xóm - lân" organization to maintain their partial self-governing of villages. However, in the context of social change, the rural organization system merges the old with the new. This represents changes in organizational structure, election standards, and the functions of village agencies, as follows:

Table 2: The organizational structure of villages and townships in post-Đổi mới Lý Sơn Island

\section{VILLAGE}

- The Village Ceremonial Committe includes the following members: Village Head of Committee, Deputy Head, Hương lê̂ (Village Ceremonial Staff); Secretary; Treasurer; Chủ xóm (hamlet head), Chủ lân (neighborhood head), Representatives of clan leaders; ông cả cựu (prestigious male seniors)

\section{HAMLET}

(Chủ xóm (hamlet head); Tri ấp (hamlet staff); Tư lễ (ceremonial staff); secretary; serviceman)

\section{Village}

In order to manage the affairs of the village, the villagers elected The Village Ceremonial Committeincluding Village Head of Committee (Cả làng),1Deputy Head, 1 Secretary, a Treasurer, andrepresentatives of each xóm (hamlet), lân (neighborhood head), representatives of clan leaders, and local prestigious male seniors. These members are responsible for the internal affairs of the village, especially the annual ceremonies in spring and autumn.According to the agreement of the Bình-Vĩnh village during the Republic of Vietnam (1954-1975), the village established the Village Ceremonial Committe to "redefine traditional meetings under the

\footnotetext{
${ }^{24}$ The Summary Report on the Implementation of Resolution No. 2006-NQ/TU of Quảng Ngãi Province Tourism Development Committee of the Provincial Party Committee during the period 2006-2010 and Orientation to 2015 (issued on October 31, 2006) and Conclusion 136 - KL/TU of the 7th Provincial Party Committee Conference on Quảng Ngãi Tourism Development 2011 - 2015 and Orientation to 2020 (No. 42 BC-HU / 2020, issued on February 1, 2016).
} 
supervision of the local government" ${ }^{25}$. The agreement defined the organizational structure, duration and role of the Village Ceremonial Committe.The village chief is the head of the Village Ceremonial Committe, namely Cả làng. Most of the elderly interviewed said that they did not fully remember the time when the Village Ceremonial Committe had been established. At present, the the Village Ceremonial Committe in the two villages of An Hải and An Vĩnh are still established in accordance with the rules of village elections and organized according to the above structure. Thereafter, the voting results will be sent to the Commune People's Committee to make anapproval decision.In fieldwork conducted in Lý Sơn, the author found that the term "Cả làng" is still used by people and Cả làng is still respected by the villagers as before.

Cả làng is still elected by the villagers, and the standard is still the same as before. "Only people with credibility and strong knowledge of customs and rituals can perform the role of Cà làng" 26 . Mr. N.H (the old $C a ̉$ làngof An Vĩnh Village) told us that, in the past, the person selected as $C \dot{a}$ làng had to be regarded as an economically rich person because he had to hold parties during the public festivals to serve the representatives of village, hamlets, and neighborhoods/subhamlets.However, this rule does not currently exist ${ }^{27}$. Compared with the period before 1945, $C a \vec{a}$ làng's voting standards have now undergone major changes. In particular, the rule that only allowed the descendants of ancient pioneers to become Cả làng is now gone. "Nowadays, $C a ̉$ làngis no longer a descendant of ancient pioneers, but is still voted by the entire village. There are 7 clans representatives in the public temple, who occupy important positions in its structure. The representatives of the 7 clans, heads of hamlets and neighborhoods all vote for Cá làng. Each term lasts 3 to 5 years; at the end of the term, he must be re-elected for the second term. For example, when An Vĩnh Village elects Cả làng, 2 heads of two hamlets (East Hamlet and West Hamlet), 4 heads of four neighborhoods, one "vạn" head, representatives of seven clans, and the cult committee all gather in the village public temple, report to the gods, prepare betel nuts and wine trays to gods and ask for their permission for village elections, and recite all the names of the candidates. All of them vote for the Cá làng. Nowadays, anyone who has the ability to work in the village can be voted, regardless of whether they are descendants of ancient pioneers or not."28

The Village Ceremonial Committe consists of Village Head of Committee, Deputy Head, Huong lễ (Village Ceremonial Staff); Secretary; Treasurer; Chủ xóm (hamlet head), Chủ lân (neighborhood head), Representatives of clan leaders; ông cả cựu (prestigous male seniors). This committeereplaces the roles of $L y$ 'truơngand members of theVillage's Five Civil Affairs Committee during the Nguyễn Dynasty (before 1945). As a result, the name of the village selfgovernment agency has been changed, but its role is basically the same as before.

The Deputy Head of the Village Ceremonial Committe is the assistant of Cả làng (village chief) whois incharge of ceremonial affairs at the village temples. The secretary and treasurer correspond to the old "Hương bổn" and are responsible for the financial management of public temples and religious places in the village.Huong lêe(village ceremonial staff) isresponsible for ritual related work, such as ritual oration, ritual music, etc. In addition, hamlet head (chủ lân), neighborhood nead (chủ xóm) and representatives of clans also have important voices in the $C a \vec{a}$ làng elections.

\footnotetext{
${ }^{25}$ Author's fieldwork notes, March, 2010.

${ }^{26}$ Quoted from an in-depth interview with Mr. V.H.Đ, 86 years old, in Lý Sơn on July 6, 2017.

${ }^{27}$ Author's fieldwork notes, February, 2019.

${ }^{28}$ Quoted from an in-depth interview with Mr. V.M.T, 38 years old, in Lý Sơn on August 2, 2019.
} 


\section{Hamlet (xóm)}

To this day, the administrative institutions below the village level are still maintained by the residents of Lý Sơn. Chủ xóm là the head of each hamlet. As assistants of Cả làng, other members namelyTri ấp (hamlet staff), Tu lễ (ceremonial staff), secretary, and serviceman take on the work of secretaries, treasurer, and ceremonial event organizers at local temples and shrines.

\section{Neighborhood/Sub-hamet (lân)}

In today's Lý Sơn Island, the unit below xóm (hamlet) is still lân (neighborhood/subhamlet). The person in charge of each lân is chủ lân (hamlet head), assisted by tri ấp (hamlet staff).In addition, in each lân, the other members, namely sceremonial staff, secretary, and serviceman who are responsible for the ceremonial events in the local temples managed by lân.

The current village organization of the residents of Lý Sorn Island is the result of the community's "inventing tradition" process, showing a trend of reorganizing traditional culture according to the actual needs of the community. In the process, we have seen the emergence of both new cultural elements and old cultural elements that have modified content or form.In terms of organizational structure, at the village level, the structure of $C a \dot{~ l a ̀ n g}$ and the Five Civil Affairs Committee before 1945 were abolished and replaced by the establishment of the Village Ceremonial Committe village composed of the village head (Cả làng) and affiliated members. Regarding the criteria for voting on Cả làng, it is no longer as strict as before.Traditionally, people only selected $C \dot{a}$ làng as descendants of the pioneer families, but now there is no such rule. In addition, the role of the village in the community has also changed. In the period before 1945, the main functions of the village self-government organization on Lý Sơn Island were to carry out festival and New Year sacrificial work in religious places, handle village affairs according to the village convention, and conduct land management in the village.Currently, the village's self-government organization performs tasks related to faith, among which " $C a ̉$ làng, chủ xóm, and chủ lân are community representatives communicating with gods”.It can be said that Lý Son's current rural system is a process of transforming traditional culture in the current rural context. "It (tradition) has not been fully restored, but there are always some considerations and modifications to adapt to current life and thinking"29.

\section{Village institutions in Lý Sơn Island: managing and carrying out ceremonial activities in the local community}

The restoration and reorganization process of the Lý Son village institutions is related to the needs of ritual activities in the local residential communities, because "if there are no cá làng, chủ xóm, and chủ lân, then no one will take care of the ritual events" ${ }^{30}$. The sentence above partially explains the current role of rural institutions in Lý Sơn Island.

Lý Son is called the "Kingdom of Garlic"; garlic is linkened to the "platinum" on the island.However, in the past few years, onion and garlic growers in Lý Sơn have faced many difficulties, such as weather affecting productivity, lower prices offered by traders, and fierce competition with other garlic sources in Ninh Thuận, Hanoi, and other regions.The life of the Lý Sơn rural "làm quê" ${ }^{31}$ families is very unstable. For peace of mind, people believe in gods worshipped in temples and shrine. In order to maintain the sacred sacrifice, the Lý Sorn people have been strengthening the role of traditional rural institutions, because people of these

\footnotetext{
${ }^{29}$ Lương Văn Hy \& Trương Huyền Chi:“Thương thảo..., p.238.

${ }^{30}$ Quoted from an in-depth interview with Mr. V.M.T, 38 years old, in Lý Sơn on August 2, 2019.

31 "Làm quê": The term refers to those who grow garlic and onions on the island of LýSơn.
} 
organizations are "serving gods" people. The author has listed the assignment of sacrificial work under the management of villages, hamlets, and neighborhoods, as follows:

Table 3: The management level map of the religious facilities responsible for sacrificial activities in An Hải Village, Lý Sơn Island

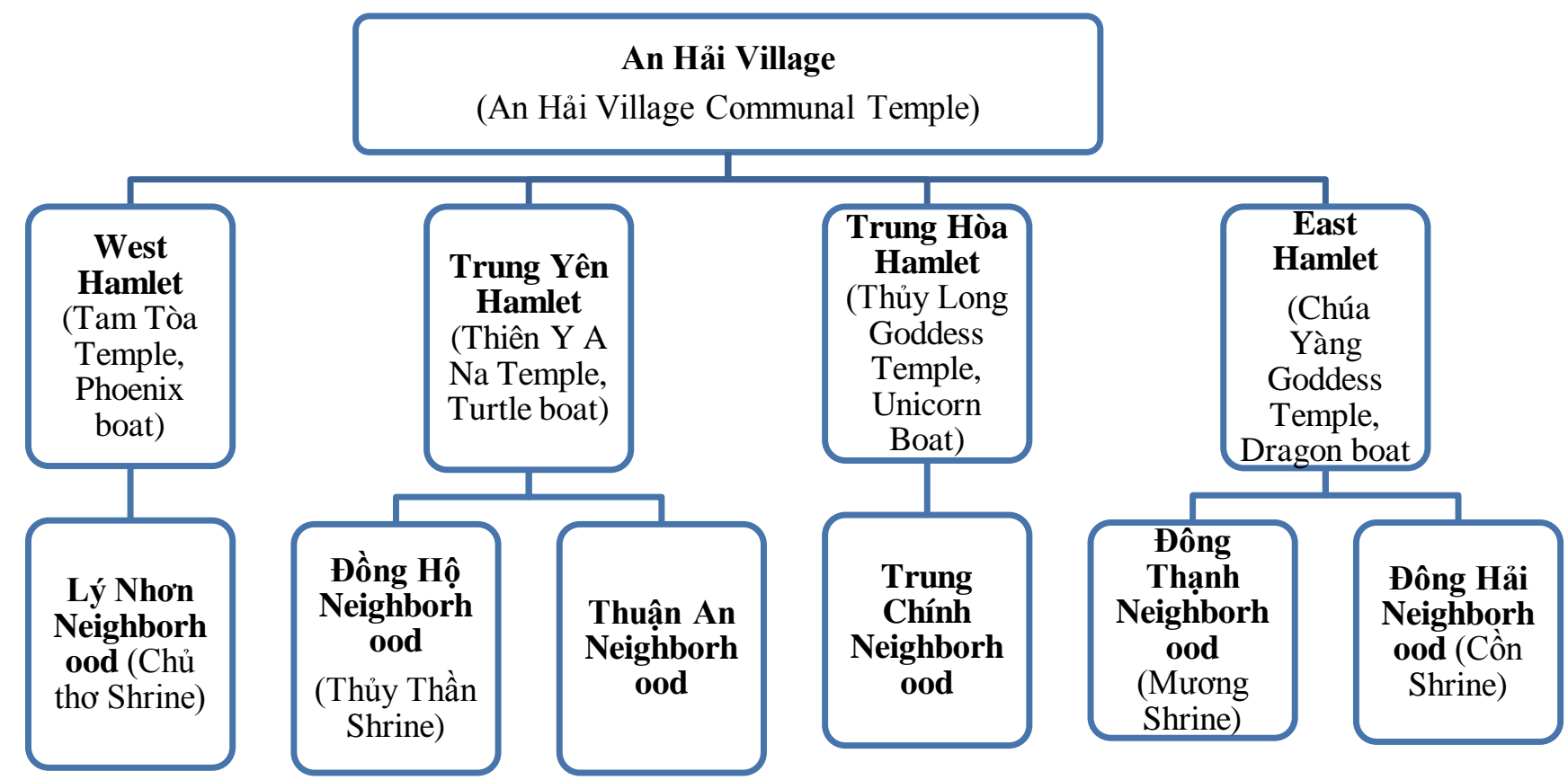

(Source: Author's fieldwork notes, Ausgust 2019)

In An Hải Village, the village is represented by Cả làng, who is responsible for the ritual events in the village's public temple. Other religious establishments belong to the lower-level units, such as Tam Tòa Temple which belongs to West Hamlet, Thiên Y A Na Temple which belongs to Trung Yên Hamlet, Thủy Long Goddess Temple which belongs to Trung Hòa Hamlet, and Chúa Yàng Goddess Temple which belongs to East Hamlet. At the grassroots level, Chủ thơ Shrine belongs to Lý Nhơn Neighborhood, Thủy thần Shrine belongs to Đồng Hộ Neighborhood, Cồn Shrine belongs to Đông Hải Neighborhood, and Mương Shrine belongs to Đông Thạnh Neighborhood.

Table 4: The management level map of the religious facilities responsible for sacrificial activities in An Vĩnh Village, Lý Sơn Island 


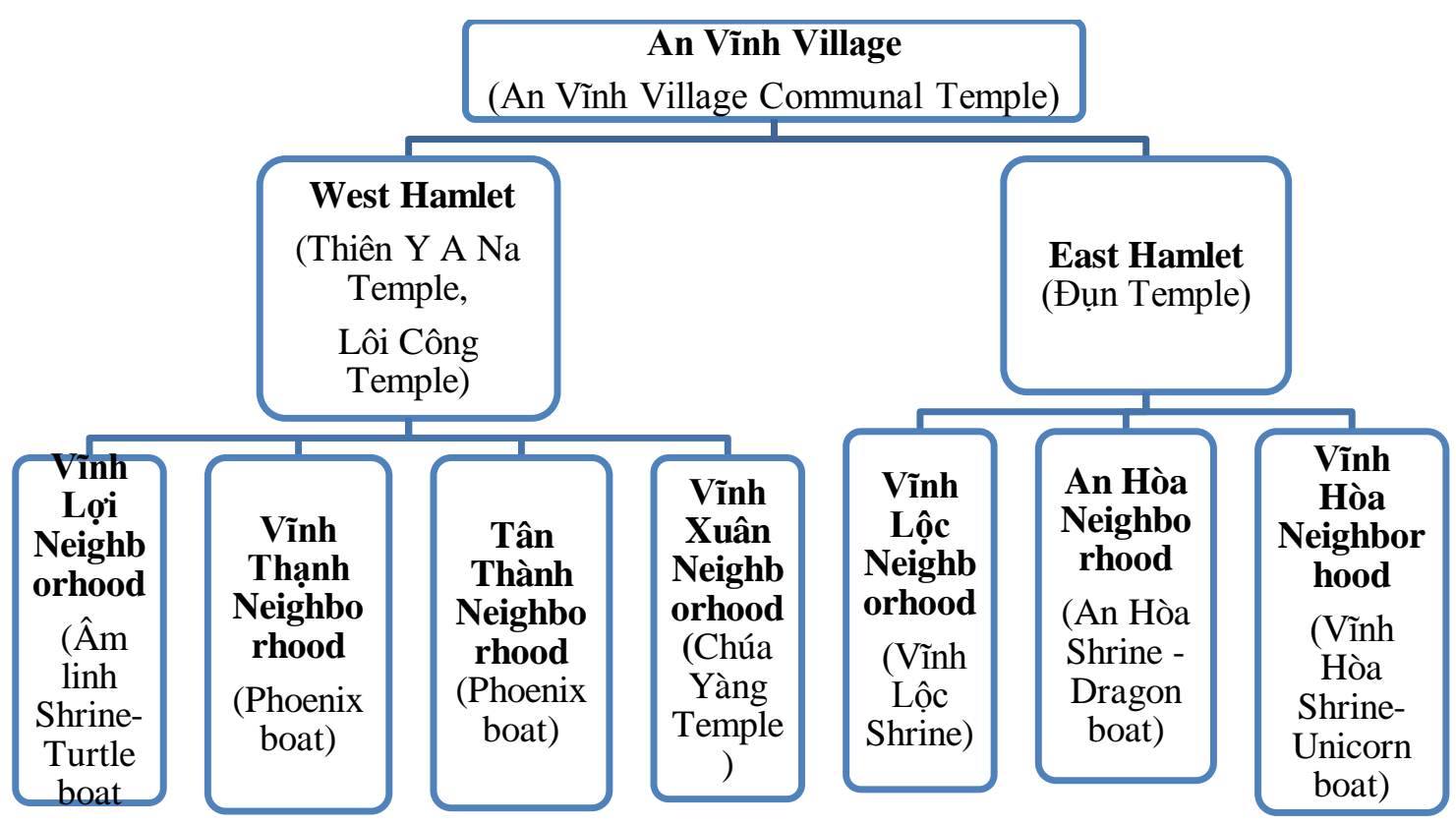

(Source: Author's fieldwork notes, Ausgust 2019)

In An Vĩnh village, $C a ̉$ làng is responsible for the rituals of the village's public temple. Thiên Y A Na Temple and Lôi Công Temple belong to West Hamlet; Đụn Temple belongs to East Hamlet, Âm linh Shrine belongs to Vĩnh Lợi Neighborhood; Chúa Yàng Goddess Shrine belongs to Vĩnh Xuân Neighborhood, Vĩnh Lộc Shrine belongs to Vĩnh Lộc Neighborhood, An Hòa Shrinebelongs to An Hòa Neighborhood, and Vĩnh Hòa Shrine belongs to Vĩnh Hòa Neighborhood. In this way, through strict vertical division management, the ritual activities of the temples are strictly managed. This provision was previously specified in the the Bình-Vĩnh Village Ceremonial Agreement in 1964, but it is still retained by Lý Sơn.

"Annual meeting or special meeting must be reported to the superior unit in advance. For example,Neighborhoodmust report toHamlet, and Hamlet must report to Village; in return, Village must announce information to Hamlet and Neighborhood so that representatives of these units can participate in the village's annual meetings. In addition to participating in the sacrifice activities of the communal temple allocated by the village, each neighborhood must "send" 2 servicemen to Village and another 1 to Hamlet so that there are enough people to hold the village and hamlet level ceremonies.Cả làng appropriately assigns the various tasks of the communal temple rituals to all hamlets and neighborhoods so that there is enough manpower to handle drums, music, ritual speeches, post-ritual activities, etc.”32

Therefore, in any institution of worship, the unit head will be the person responsible for ritual activities in that institution. For example, in the case of the An Vĩnh Village's communal temple, Mr. V.M.T said as follows:"When the communal temple holds the Paracel Islands Troop Sacrificial Ceremony (Lễ Khao lề thế lính Hoàng Sa), the heads of two hamlets, the heads of the four neighborhoods, and representatives of seven ancient pioneer families must be present.When West Hamlet hold the ritual at its temple, the head of West Hamlet must invite the head of East Hamlet and two heads Vĩnh Lợi and Cồn Trong Neighborhoods to attend the event. He also invites the Cả làng; however, he himself must perform the role of the host of ceremony. Cả làng is unable to preside over the ceremony at the lower level. Instead, he only participates in service to the gods during the ceremony.Cả làng will check whether the head of the hamlet has made proper sacrifices and whether the sacrificial items are full. If any errors are found, he will hold a

\footnotetext{
${ }^{32}$ Author's fieldwork notes, 2010.
} 
meeting in the communal temple in a few days to evaluate and correct them. For example, in the Thiên Y A Na ceremony, the sacrifice must include a pig;the head and tail (cooked) of the pig must be displayed on the sacrificial table. In fact, this year is so difficult that people in hamlet only offer chicken. Cả làng may correct and conclude that the hamlet should retain the pig sacrifice rule at the annual ceremony"33.

It can be said that the establishment and maintenance of the Lý Sơn Island village organization are mainly responsible for the task of managing and organizing cultural relics to meet the actual religious needs of local residents. It is the truth that"the village ceremonial committe takes care of all sacrifices. Therefore, if these committee members are still there, village customs and worship in Lý Son will remain." 34 .

\section{Conclusion}

Since the Nguyễn Dynasty, the village has been the traditional social organization of the residents of Lý Sơn Island. Over time, the island still maintains a hierarchical management level from village to hamlet and neighborhood.However, through historical documents and on-site investigation, I found that the village's organizational structure and community role have undergone certain changes. The current rural system on the island is the result of the "inventing traditions" process of the islanders. In this process, some outdated cultural elements will be lost, some outdated cultural elements will disappear, and some new cultural elements that can meet the needs of the community and its social environment will be formed and developed.The restoration and restructuring process of Lý Sơn's rural institutions is the result of changes in state policies and fulfilling the obligation of "serving the gods" to demonstrate people's belief in gods. The rural system that once existed and does exist in Lý Sơn proves the existence of "traditional" cultural values in modern society.In Hobsbawm's (2000) words, there is no separation or opposition between modernity and tradition. "Inventing tradition" may occur in any society, at any time, especially in a society that has undergone tremendous changes. This process is closely related to the restructuring trend of the traditional culture that is widely occurring in contemporary Vietnamese villages.By restoring traditional cultural values, the community reaffirms its cultural identity.

\section{Acknowledgement}

I would like to take this opportunity to express my warm thanks to Board of editors, my family, colleagues and brother in assisting convenient conditions for my research paper.

\section{Reference}

[1] Cao Nguyễn Ngọc Anh: Lễ hội khao lề thế lính Hoàng Sa ở đảo Lý Sơn, tỉnh Quảng Ngãi(The Paracel islands Troop Sacrificial Ceremony), Master Disseration in Ethnology. University of Social Sciences and Humanities, Vietnam National University - Ho Chi Minh City, 2011.

[2] Ban chấp hành Đảng Bộ huyện Lý Sơn (Lý Sơn District Communist Party Committee Executive Committee): Lịch sủ Đảng bộ huyện Lý Sơn (History of Lý Sơn District Communist Party Committee), Quảng Ngãi Printing Factory, 2000.

[3] Chi cục Thống kê Huyện Lý Sơn tỉnh Quảng Ngãi (Bureau of Statistics of Lý Sơn District, Quảng Ngãi Province), Niêm giám thống kê huyện Lý Sơn (Lý Sơn District Statistical Yearbook), 2017.

\footnotetext{
${ }^{33}$ Quoted from an in-depth interview with Mr. V.M.T, 38 years old, in Lý Sơn on August 2, 2019

${ }^{34}$ Quoted from an in-depth interview with Mr. V.M.T, 38 years old, in Lý Sơn on August 2, 2019.
} 
[4] Nguyễn Thị Phương Châm \& Đỗ Lan Phương: Làng ven đô và sụ biến đổi văn hóa Truờng hợp làng Xuân Đỉnh, huyện Tù̀ Liêm, TP. Hà Nội (Peri-urban village and cultural change - Case of Xuân Đỉnh village, Từ Liêm district, Hanoi),Social Sciences Press, 2016.

[5] Eric Hobsbawn \& Terence Ranger: The Invention of Tradition, Cambridge University Press, 2000.

[6] Hội Khoa học lịch sử Việt Nam (Vietnam Association for Historical Sciences), Làng Việt đối diện tương lai hồi sinh quá khú (Vietnamese villages: facing the future and reviving the past), Danang: Danang Press, 2007.

[7] Lương Văn Hy \& Trương Huyền Chi:“Thương thảo để tái lập và sáng tạo "truyền thống”: Tiến trình tái cấu trúc lễ hội cộng đồng tại một làng Bắc bộ (Negotiation to Re-establish and to Invent "Tradition": The Re-structuring of Community Festival in a North Vietnamese Village), in Nhũng thành tụu nghiên cúu bước đầu của Khoa Nhân học (Primary research achievements of the Department of Anthropology), ed. the Department of Anthropology, VNU-HCM, pp. 235-279, Vietnam National University - Ho Chi Minh City Press, 2012

[8] Sở Văn hóa thông tin Quảng Ngãi (Quảng Ngãi Department of Culture and Information): Quảng Ngãi - đất nước - con nguời và văn hóa (Quảng Ngãi: the land, the people, and culture), Quảng Ngãi Printing Factory, Quảng Ngãi, 2002.

[9] Ủy ban nhân dân tỉnh Quảng Ngãi \& Sở Khoa học công nghệ và Môi trường (People's Committee of Quảng Ngãi Province \& Department of Science, Technology and Environment): Văn hóa truyền thống đảo Lý Sơn (The traditional culture of Lý Sơn Island), Quảng Ngãi Printing Factory, Quảng Ngãi, 2002.

[10] Ủy ban nhân dân tỉnh Quảng Ngãi (People's Committee of Quảng Ngãi Province): Địa chí Quảng Ngãi (Geographical Notes of Quảng Ngãi), Encyclopedia Press, Hanoi, 2008.

[11] Nguyễn Đăng Vũ: Quảng Ngãi một số vấn đề lịch sủ văn hóa (Quảng Ngãi: some historical and cultural issues),Social Sciences Press, Hanoi, 2008.

[12] Phạm Trung Việt: Non nước xú Quảng (The Quảng Region), Youth Press, Ho Chi Minh City, 2005.

[13] Yang Mingchuan: "Reshaping Peasant Culture and Community: Rural Industrialization in a Chinese Village”, Modern China, 20(2), 1994, pp.157-179.

[14] Anonymous: "Ngành Văn hóa tổng kết 15 năm thực hiện Nghị quyết Trung ương 5 (khóa VIII) (Summary of the Ministry of Culture on the implementation of Central Resolution 5 (Term 8) within 15 years)”, http://dangcongsan.vn/chinh-tri/nganh-van-hoa-tong-ket-15nam-thuc-hien-nghi-quyet-trung-uong-5-khoa-viii-335544.html, Accessed on March 7, 2020.

[15] Anonymous: "Bảng tra Các chức quan, phẩm tước, học vị thời phong kiến Việt Nam (Checklist of official titles and degrees in Vietnam's feudal system)”, http://hotovietnam.org/Tin-tuc-va-Su-kien/Khoa-hoc--Lich-su/175-Bang-tra-Cac-chucquan-pham-tuoc-hoc-vi-thoi-phong-kien-Viet-Nam, Accessed on September 23, 2020.

[16] Bảy Tám (compiled): “'Luật làng' thời phong kiến Việt Nam (Bài 1): Đội ngũ 'dân quan' (The "Village Law" in the Feudal System of Vietnam (Part 1): The "civilian" team)", https://baophapluat.vn/dan-sinh/luat-lang-thoi-phong-kien-viet-nam-bai-1-doi-ngu-danquan-392784.html, Accessed on September 23, 2019.

[17] Politburo Resolution No. 24 NQ-TW of October 16, 1990, term VI on "Strengthening religious work in a new 
situation,http://btgcp.gov.vn/Plus.aspx/vi/News/38/0/240/0/1081/Tu_su_doi_moi_nhan_th uc_den_su doi_moi ve_Chinh_sach_Ton_giao, Accessed on September 23, 2020. 